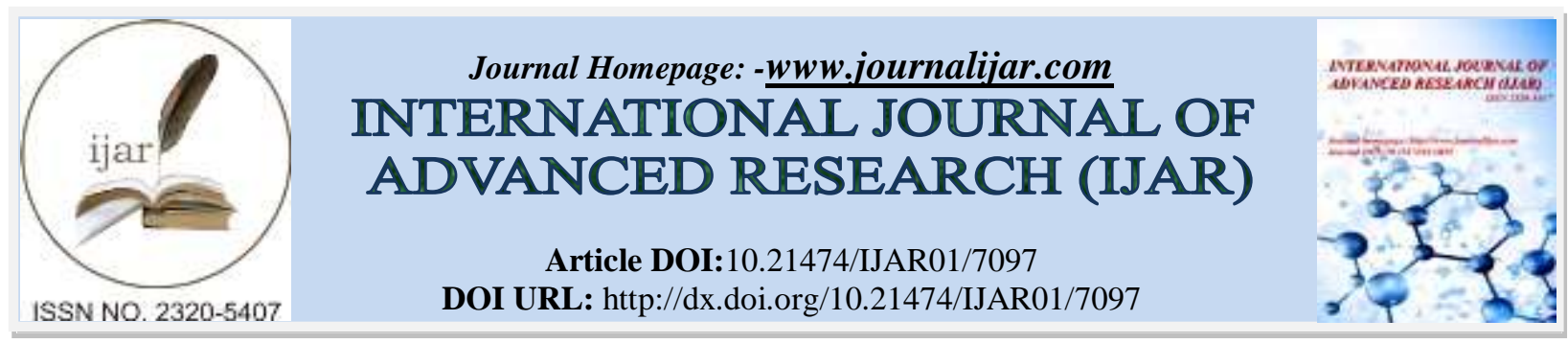

RESEARCH ARTICLE

\title{
EFFECT OF THE FINISH LINE DESIGN UPON THE MARGINAL SEAL OF A COMPLETE CAST CROWN.
}

Dr. Mohammad Altaf Tantray, MDS Prosthodontics, Government Dental College, Srinagar.

\section{Manuscript Info}

Manuscript History

Received: 14 March 2018

Final Accepted: 16 April 2018

Published: May 2018

Keywords:-

Precision, marginal fit, finish line.

\begin{abstract}
Introduction: The successful clinical longevity of any indirect dental restoration is dependent upon the precision in its marginal fit. Many factors influence the marginal fit of a complete cast crown like type of cement, cementation pressure, venting, and internal relief of the crown.

Aims and objectives: this study was conducted to evaluate the influence of a finish line design of a tooth preparation upon the sealing ability of a complete cast crown.

Materials and methods: Thirty complete cast crowns were fabricated from three types of $8 \mathrm{~mm}$ wide and $6 \mathrm{~mm}$ high stainless steel dies with $5^{0}$ angle of convergence differing only in finish line configuration i.e., one with $90^{\circ}$ shoulder, other with $90^{\circ}$ shoulder with bevel and another with chamfer. Ten crowns from each type of the die were made. A measured volume of autopolymerising resin (Duralay, Reliance, and Mfg.) was poured into castings to make direct Duralay dies. Crowns were cemented upon the Duralay dies and die sectioning was done with diamond discs. The cement space thickness was measured at the middle of the finish line with reflecting microscope.

Results: There is statistically significant difference in the seal of the finish line $90^{\circ}$ shoulder versus $90^{\circ}$ shoulder with bevel and $90^{\circ}$ shoulder versus chamfer of 0.00001 that is statistically significant at $p<0.05$ and $90^{\circ}$ shoulder with bevel versus chamfer showed $p$ value of 0.49 that is highly insignificant at $\mathrm{p}<0.05$.

Conclusion: Within the limitations of the study, it can be concluded that finish line design of any preparation affects the sealing ability of the complete cast crown.
\end{abstract}

Copy Right, IJAR, 2018,. All rights reserved.

\section{Introduction:-}

Precision in the marginal fit of a complete cast crown maximizes its clinical longevity. Discrepancy in the marginal seal of a complete cast crown results in microleakage, plaque retention, secondary caries, pulpal decay and periodontal disease ${ }^{1,2}$. Sealing discrepancies in the range of 100 micrometers is clinically acceptable with regard to longevity of the restoration ${ }^{3,4}$. Omar proposed that shoulder with bevel seals better than $90^{0}$ shoulder in Porcelain fused to metal crown ${ }^{5}$. Shillinburg ${ }^{6}$ stated that shoulder finish line has less marginal distortion as compared to chamfer after porcelain firing. Fusayama et al ${ }^{7}$ cemented cast full crowns onto extracted teeth prepared with the 90degree shoulder, the 45-degree shoulder, and featheredge margins. They reported that the feather edge margin provided the best sealing effect followed by the 45 -degree shoulder and 90-degree shoulder respectively. 
Aims and objectives:

This study was conducted to evaluate the effect of finish line design upon the marginal seal of a complete cast crown.

\section{Materials and methods:-}

\section{Die preparation:}

Three $8 \mathrm{~mm}$ wide and $6 \mathrm{~mm}$ high stainless steel dies are machined to simulate the size of an average molar with shoulder, shoulder with bevel and chamfer finish lines. Each die is machined with $5^{0}$ angle of convergence per axial wall and the occlusal surface is dimpled to reorient the crowns properly.

\section{Complete cast crown construction:}

Ten complete cast crowns are fabricated from each die. Wax patterns were made from molten inlay wax (Bego, Germany) kept in electrically mentained water bath (Bego, Germany) at $160^{\circ} \mathrm{F}$. The wax patterns invested in phosphate bonded investment (Degudent, DENTSPLY, USA) were cast in cobalt chromium alloy using induction casting machine (Ducatron, UGIN, France). The complete cast crowns were retrieved, desprued and pickled.

\section{Direct die fabrication:}

A measured volume of methyl methacrylate (Duralay; Reliance Dental Mfg. Co, Chicago, III) was poured into the castings to make direct dies.

\section{Complete cast crown cementation:}

The crowns were cemented onto Duralay dies with zinc phosphate cement (Tenacin, Caulk) under 100 pounds pressure for 10 minutes. The orange wood stick was used for uniform and even distribution of the pressure with an Instron testing machine (Instron Corp, Canton, and Mass).Then, the centre wise die sectioning was done with a diamond disk on an ultrastructural analysis cutting machine (Buehler Ltd, Evanston, III). The measurement of the cement space thickness at the middle of the finish line of each half of each die was done with reflecting microscope. Then, the average marginal cement space thickness for each die was determined.

\section{Results:-}

The mean of the cement space thickness at the shoulder, shoulder with bevel and chamfer finish lines are $0.134 \mathrm{~mm}$, $0.089 \mathrm{~mm}$ and $0.094 \mathrm{~mm}$ with standard deviation of $0.0176,0.089$ and 0.0179 respectively as shown in the table 1 and figure 1. The measurements of the marginal cement space thickness of the complete cast crowns cemented upon the Duralay dies when subjected to one way analysis ANOVA showed p-value of 0.00001 that is statistically significant at p-value of 0.05 .

Table1:- The marginal cemental space thickness of the cast crowns cemented at the Duralay dies in $\mathrm{mm}$.

\begin{tabular}{|c|c|c|c|}
\hline & Shoulder & Shoulder with bevel & chamfer \\
\hline i. & 0.125 & 0.089 & 0.092 \\
\hline ii. & 0.151 & 0.091 & 0.103 \\
\hline iii. & 0.145 & 0.095 & 0.112 \\
\hline iv. & 0.175 & 0.079 & 0.115 \\
\hline v. & 0.127 & 0.078 & 0.089 \\
\hline vi. & 0.131 & 0.067 & 0.073 \\
\hline vii. & 0.124 & 0.087 & 0.095 \\
\hline viii. & 0.129 & 0.098 & 0.121 \\
\hline ix. & 0.115 & 0.099 & 0.075 \\
\hline X. & 0.125 & 0.115 & 0.072 \\
\hline mean & 0.134 & 0.089 & 0.094 \\
\hline Standard & 0.0176 & 0.0133 & 0.0179 \\
\hline
\end{tabular}


Table2:- Comparison of the seals the various finish line designs create in a complete cast crown by ANOVA (FTest)

\begin{tabular}{|l|l|l|l|}
\hline & $\begin{array}{l}\text { Shoulder versus shoulder } \\
\text { with bevel }\end{array}$ & Shoulder versus chamfer & $\begin{array}{l}\text { Shoulder with bevel versus } \\
\text { chamfer }\end{array}$ \\
\hline $\mathrm{P}$ value by F test & 0.00001 & 0.000086 & 0.49 \\
\hline $\mathrm{P}<0.05$ significant & Statistically significant & Statistically significant & Highly insignificant \\
\hline
\end{tabular}

Figure1:- Distribution of marginal cemental space thickness among the various finish lines.

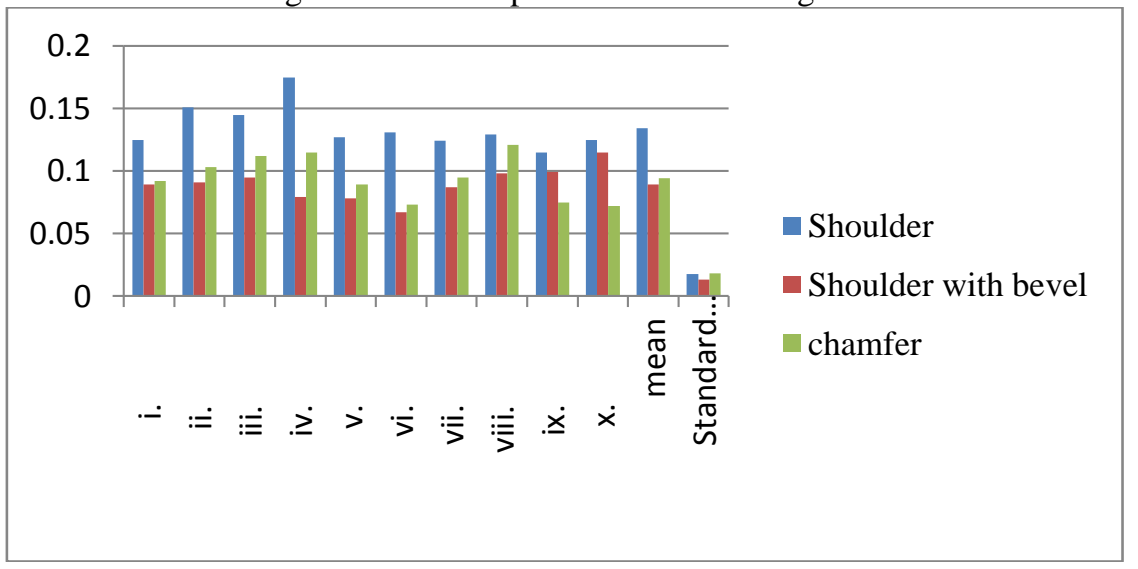

Figure2:- Comparison of the seal the finish line configuration creates in the complete cast crown by F-test

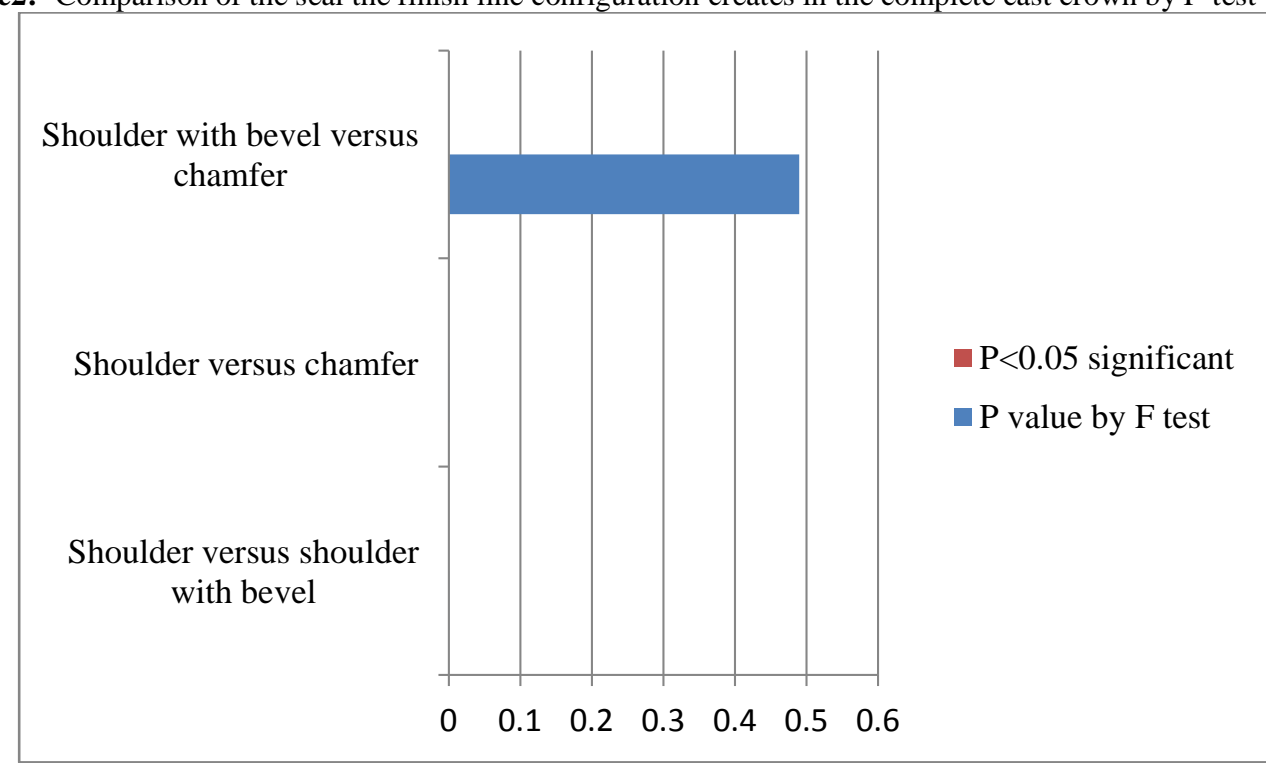

\section{Discussion:-}

Gavelis J.R. et $\mathrm{al}^{8}$ has shown that marginal configuration of a complete cast crown preparation affects the marginal fit of the cast crown.

It has been proposed that feather edge seals better than $90^{\circ}$ shoulder finish line. The cast crowns seat better on $90^{\circ}$ shoulder preparations than feather and $90^{\circ}$ shoulders with bevel preparations. In this study, the $90^{\circ}$ shoulder with bevel with average marginal opening of $0.089 \mathrm{~mm}$ seals better than $90^{\circ}$ shoulder and $90^{\circ}$ shoulder with bevel finish line preparations that opened at margins by 0.134 and $0.094 \mathrm{~mm}$ respectively. There is statistically significant difference in the seal the finish line $90^{\circ}$ shoulder versus $90^{\circ}$ shoulder with bevel and $90^{\circ}$ shoulder versus chamfer of 0.00001 that is statistically significant at $p<0.05$ and $90^{\circ}$ shoulder with bevel versus chamfer showed $p$ value of 0.49 that is highly insignificant at $\mathrm{p}<0.05$ as shown in table 2 and figure 2. 
Holmes et $\mathrm{al}^{9}$ reported sealing discrepancy values of $0.036 \mathrm{~mm}$ for electroformed metal-ceramic crowns with a chamfer configuration; these values were lower than those observed in the present study. The lower result may be due to measurement carried out in non cemented crowns.

Fusayama et $\mathrm{al}^{10}$ cemented cast full crowns onto extracted teeth prepared with the 90 -degree shoulder, the 45 -degree shoulder, and featheredge margins. They reported that the featheredge margin provided the best sealing effect followed by the 45-degree shoulder and 90-degree shoulder, respectively. Obviously, it is seen in the present study that the $90^{0}$ shoulder with bevel seals better than shoulder configuration.

Conclusion: Within the limitations of the study, it can be concluded that finish line design of any preparation affects the sealing ability of the complete cast crown.

\section{References:-}

1. Sorensen SE, Larsen IB, Jorgensen KD. Gingival and alveolar bone reaction to marginal fit of subgingival crown margins. Scand J Dent Res1986; 94:109-14

2. Felton DA, Kanoy BE, Bayne SC, Wirthman GP. Effect of in vivo crown margin discrepancies on periodontal health. J Prosthet Dent 1991; 65:357-64.

3. McLean JW, von Fraunhofer JA. The estimation of cement film thickness by an in vivo technique. Br Dent $\mathbf{J}$ 1971; 131:107-11.

4. Fransson B, Oilo G, Gjeitanger R. The fit of metal-ceramic crowns, a clinical study. Dent Mater 1985; 1:197-9.

5. Omar R. Scanning electron microscopy of the marginal fit of ceramometal restorations with facially butted porcelain margins. J Prosthet Dent 1987; 58:13-9.

6. Shillingburg HT Jr, Hobo S, Fisher DW. Preparation design and margin distortion in porcelain-fused-to-metal restorations. J Prosthet Dent 1973; 29:276-84.

7. Fusayama T, Ide K, Hosoda H. Relief of resistance of cement of full cast crowns. J Prosthet Dent 1964; 14:95.

8. Gavels J.R., Morency. J. D., Riley, E. D., and Sozio, R. B.: The elfect of various finish line preparations on the marginal seal and occlusal seat of full crown preparations. J PROSTHET 45:138, 1981.

9. Holmes JR, Pilcher ES, Rivers JA, Stewart RM. Marginal fit of electroformed ceramometal crowns. J Prosthodont 1996; 5:111-4.

10. Fusayama T, Ide K, Hosoda H. Relief of resistance of cement of full cast crowns. J Prosthet Dent 1964;14:95 